\title{
The cellular prion protein: a player in immunological quiescence
}

\author{
Maren K. Bakkebo ${ }^{1}$, Sophie Mouillet-Richard ${ }^{2}$, Arild Espenes ${ }^{1}$, Wilfred Goldmann ${ }^{3}$, \\ Jörg Tatzelt ${ }^{4}$ and Michael A. Tranulis ${ }^{1 *}$
}

\begin{abstract}
'Department of Basic Sciences and Aquatic Medicine, Faculty of Veterinary Medicine and Biosciences, Norwegian University of Life Sciences, Oslo, Norway, ${ }^{2}$ UMR-S1124, INSERM, Université Paris Descartes, Sorbonne Paris Cité, Paris, France, ${ }^{3}$ The Roslin Institute, Royal (Dick) School of Veterinary Studies, University of Edinburgh, Edinburgh, UK, ${ }^{4}$ Biochemistry of Neurodegenerative Diseases, Institute of Biochemistry and Pathobiochemistry, Ruhr University Bochum, Bochum, Germany
\end{abstract}

OPEN ACCESS

Edited by:

Masaaki Murakami,

Hokkaido University, Japan

Reviewed by:

Daisuke Kamimura,

Hokkaido University, Japan Hideki Ogura,

Yale University, USA

*Correspondence:

Michael A. Tranulis,

Department of Basic Sciences and

Aquatic Medicine, Faculty of

Veterinary Medicine and Biosciences,

Norwegian University of Life

Sciences, Campus Adamstuen,

Oslo 0033, Norway

michael.tranulis@nmbu.no

Specialty section:

This article was submitted to Inflammation, a section of the journal

Frontiers in Immunology

Received: 10 July 2015 Accepted: 19 August 2015 Published: 02 September 2015

Citation:

Bakkebø MK, Mouillet-Richard S, Espenes A, Goldmann W, Tatzelt J and Tranulis MA (2015) The cellular prion protein: a player in immunological quiescence.

Front. Immunol. 6:450. doi: 10.3389/fimmu.2015.00450
Despite intensive studies since the 1990s, the physiological role of the cellular prion protein $\left(\mathrm{PrPC}^{\mathrm{C}}\right)$ remains elusive. Here, we present a novel concept suggesting that $\mathrm{PrPc}^{\mathrm{C}}$ contributes to immunological quiescence in addition to cell protection. $\mathrm{PrP}^{\mathrm{C}}$ is highly expressed in diverse organs that by multiple means are particularly protected from inflammation, such as the brain, eye, placenta, pregnant uterus, and testes, while at the same time it is expressed in most cells of the lymphoreticular system. In this paradigm, $\mathrm{PrP}^{\mathrm{C}}$ serves two principal roles: to modulate the inflammatory potential of immune cells and to protect vulnerable parenchymal cells against noxious insults generated through inflammation. Here, we review studies of $\mathrm{PrP}^{\mathrm{C}}$ physiology in view of this concept.

\footnotetext{
Keywords: prion protein, immune privilege, immune modulation, cytoprotection, cell signaling, inflammation, neurodegeneration, Alzheimer
}

\section{Introduction}

The cellular prion protein $\left(\mathrm{PrP}^{\mathrm{C}}\right)$ is known for its crucial involvement, via its scrapie isoform $\mathrm{PrP}^{\mathrm{Sc}}$, in the development of transmissible spongiform encephalopathies (TSEs), such as Creutzfeldt-Jakob disease in man and scrapie in sheep and goats. In these fatal diseases, the spontaneous or templatedirected misfolding of $\operatorname{PrP}^{\mathrm{C}}$ into abnormal $\mathrm{PrP}^{\mathrm{sc}}$ subverts $\mathrm{PrP}^{\mathrm{C}}$ s normal function and causes synaptic loss and neuronal demise $(1,2)$. Despite extensive investigations for three decades, $\operatorname{PrP}^{\mathrm{C}}$ remains a conundrum. What is the major physiological role of this protein and why does it exist under a plethora of isoforms and interact with so many partners? Why do Prnp knockout mice develop normally and without major phenotypic alterations, although $\operatorname{PrP}^{\mathrm{C}}$ is ubiquitous and highly conserved between species? Here, based on the current knowledge of $\operatorname{Pr}^{\mathrm{C}}$ function, we provide an overview of its potential contribution to a phenomenon generically known as immune privilege, providing a new angle to the question of the physiological role of $\mathrm{PrP}^{\mathrm{C}}$.

During evolution of the vertebrate immune system, the potency of inflammatory responses has increased, not least during the transition from ectothermic (fish, amphibians, and reptiles) to endothermic (birds and mammals) species, dramatically increasing $\mathrm{O}_{2}$ consumption and reactive oxygen species (ROS) generation (3). In parallel with increasing immunological firepower, to combat intruding microorganisms and cancer cells, several anti-inflammatory and protective measures have evolved to shield "innocent bystander" cells from inflammatory damage. Interestingly, major areas of modern medical treatment are concerned with dampening inflammatory responses. In organs such as the eye, the brain, pregnant uterus, and testicles, inflammation can have devastating consequences. One fascinating development to protect such tissues with limited regenerative capacity is the 
evolution of immune privilege. This phenomenon is established through combinations of physical barriers and circulatory adaptations, together with organ expression of potent cell surface and soluble immunomodulatory factors (4). The principal concept presented in this review is that $\operatorname{PrP}^{\mathrm{C}}$ serves an anti-inflammatory and protective role. This explains the prevalent observation that phenotypes due to loss of $\mathrm{PrP}^{\mathrm{C}}$ are minor if detectable at all under physiological conditions, while clearly evident under stress and particularly under inflammation in immune-privileged organs, such as the brain.

\section{Immune Privilege}

In the late nineteenth century, VanDooremaal and later, in the 1940s, Medawar pioneered studies that defined "immune privilege" after studying grafts that survived after being transplanted into the brain or anterior chamber of the eye (5) [reviewed in Ref. (6)]. Classically, immune-privileged sites were the central nervous system (CNS), the anterior chamber of the eye, the placenta and fetus, and testicles. Immune privilege was considered a static phenomenon, mainly resulting from anatomical and circulatory peculiarities, such as an apparent lack of lymphatic drainage. This concept was supported by the discovery of the blood-brain barrier and later the blood-testis barrier (7).

Today, our understanding of immune privilege, often referred to as immunological quiescence, is vastly extended, and may be defined as a dynamic and highly complex interplay between anatomical, physiological and immunoregulatory adaptations, which together restrict, deviate, and block inflammatory processes in the privileged tissue $(8,9)$. Moreover, many organs and cellular niches can obtain immune privilege, and certain elements of immune privilege have been observed in tumor growth and during chronic inflammation. Importantly, immune privilege is not a general immunosuppression, but involves tight control and often downregulation of those immune responses that potentially cause severe tissue damage. These include cytotoxic T cells, natural killer cells (NK), and pro-inflammatory cytokines.

Several cell surface and extracellular proteins play important parts in immune privilege, e.g., the immunomodulatory enzyme indolamine 2,3-dioxygenase (IDO) which causes a local depletion of L-tryptophan and thereby halts proliferation of $\mathrm{T}$ cells (10), the apoptosis-stimulating receptor ligand couple Fas/FasL (11), tumor necrosis factor alpha apoptosis inducing ligand (TRAIL) (12), and transforming growth factor beta (TGF- $\beta$ ) (13), amongst others. In addition, in many immune-privileged organs, cells, such as neurons, have low expression of major histocompatibility complex (MHC) class Ia molecules, which confer fundamental protection from cytotoxic T cells [reviewed in Ref. (4)]. They instead express non-classical MHC class Ib molecules that downregulate NK cell activity. Novel immunomodulating proteins are constantly being discovered $(14,15)$, and considering the importance of monitoring and fine-tuning inflammatory responses in particularly vulnerable organs, there are probably many more to come.

Another contribution to immune privilege is active recruitment of $\mathrm{CD}^{+} \mathrm{CD}^{2} 5^{+}$Foxp $3^{+}$regulatory T cells (TREGs), which suppress the activation of other T cells, both directly and indirectly [reviewed in Ref. (16)]. TREGs exert their immunosuppressive activities in various ways, such as cell-cycle arrest via suppressive cytokines, e.g., IL-10 and TGF- $\beta$ or cell surface expression and secretion of molecules, such as Galectin-1. They can induce apoptosis in IL-2-dependent T cells via IL-2 uptake or direct cytolysis via, e.g., granzyme. Indirectly, TREGs can also exert their effects on antigen-presenting cells, impairing their co-stimulatory or antigen-presenting activity or inducing them to remain naïve.

\section{Posttranslational Modifications of PrPc}

Cellular prion protein is a 210-residue glycoprotein, encoded by a single-copy gene denoted $\operatorname{Prnp}(17,18)$. It is mainly located at the outer leaflet of the plasma membrane, attached by a glycosylphosphatidylinositol (GPI) anchor (19) and exists in many forms due to variable $\mathrm{N}$-glycosylation (20) and proteolytic processing $(21,22)$.

Mammalian $\operatorname{PrP}^{\mathrm{C}}$ has two N-X-T sequence motifs for glycosylation (Figure 1) and most $\operatorname{PrP}^{\mathrm{C}}$ isolated from tissues is indeed diglycosylated. The glycosylation sites of mammalian $\mathrm{PrP}^{\mathrm{C}}$ appear invariant and they are conserved in avian, reptilian, and amphibian $\mathrm{PrP}^{\mathrm{C}}$ sequences; glycosylation promotes trafficking of $\mathrm{PrP}^{\mathrm{C}}$ to the plasma membrane and may increase $\mathrm{PrP}^{\mathrm{C}}$ half-life. As a response to oxidative stress, mammalian $\mathrm{PrP}^{\mathrm{C}}$ can be cleaved near codon 90 generating fragments PrP-N2 and PrP-C2 $(22,23)$. Alternatively, while passing the late-Golgi compartment, a subset of $\mathrm{PrP}^{\mathrm{C}}$ is processed into two fragments PrP-N1 and PrP-C1 (Figure 1, C1 processing site) (24). The $\mathrm{N}$-terminal PrP-N1 fragment is secreted, whereas the remaining C-terminal fragment PrP-C1 remains attached to the cell membrane. Whether it is localized in lipid rafts like full-length $\mathrm{PrP}^{\mathrm{C}}$ remains to be shown.

PrP-C1 may also be generated on the cell membrane (23), while C-terminal shedding by ADAM10 can release full-length $\operatorname{PrP}^{\mathrm{C}}$ (and PrP-C1) from the membrane $(25,26)$. The generation of truncated PrP-C1 is conserved in avian $\mathrm{PrP}^{\mathrm{C}}$ and is likely to occur also in other vertebrates, intriguingly it is also seen in other prion family genes (PRND, SPRN) (27) and even in the structurally related zinc-transporter ZIP10 (SLC39A10) (28). Although $\operatorname{PrP}^{\mathrm{C}}$ processing is in principal conserved, there is evidence that the degree of cleavage and shedding is dependent on the $\operatorname{PrP}^{\mathrm{C}}$ sequence (29). Questions remain whether cleavage and $\mathrm{PrP}-\mathrm{C} 1$ specifically may influence regulation and function attributed to normal prion protein and because full-length $\operatorname{PrP}^{\mathrm{C}}$ and PrP-C1 are not always experimentally differentiated it is often left unresolved which of the isoforms is actually responsible for the observed activity. However, the recent finding that PrP-C1 exhibited myelinotrophic activity in the peripheral nervous system strengthens the concept that all the various $\operatorname{PrP}^{\mathrm{C}}$ molecules have physiological importance (30).

\section{The Intrinsically Disordered N-Terminal Domain of PrPc}

Structural studies revealed that $\operatorname{PrP}^{\mathrm{C}}$ is composed of an intrinsically disordered $\mathrm{N}$-terminal and a structured C-terminal domain, containing three $\alpha$-helical regions and a short, twostranded $\beta$-sheet (31-33). Classically, the activity of a protein 


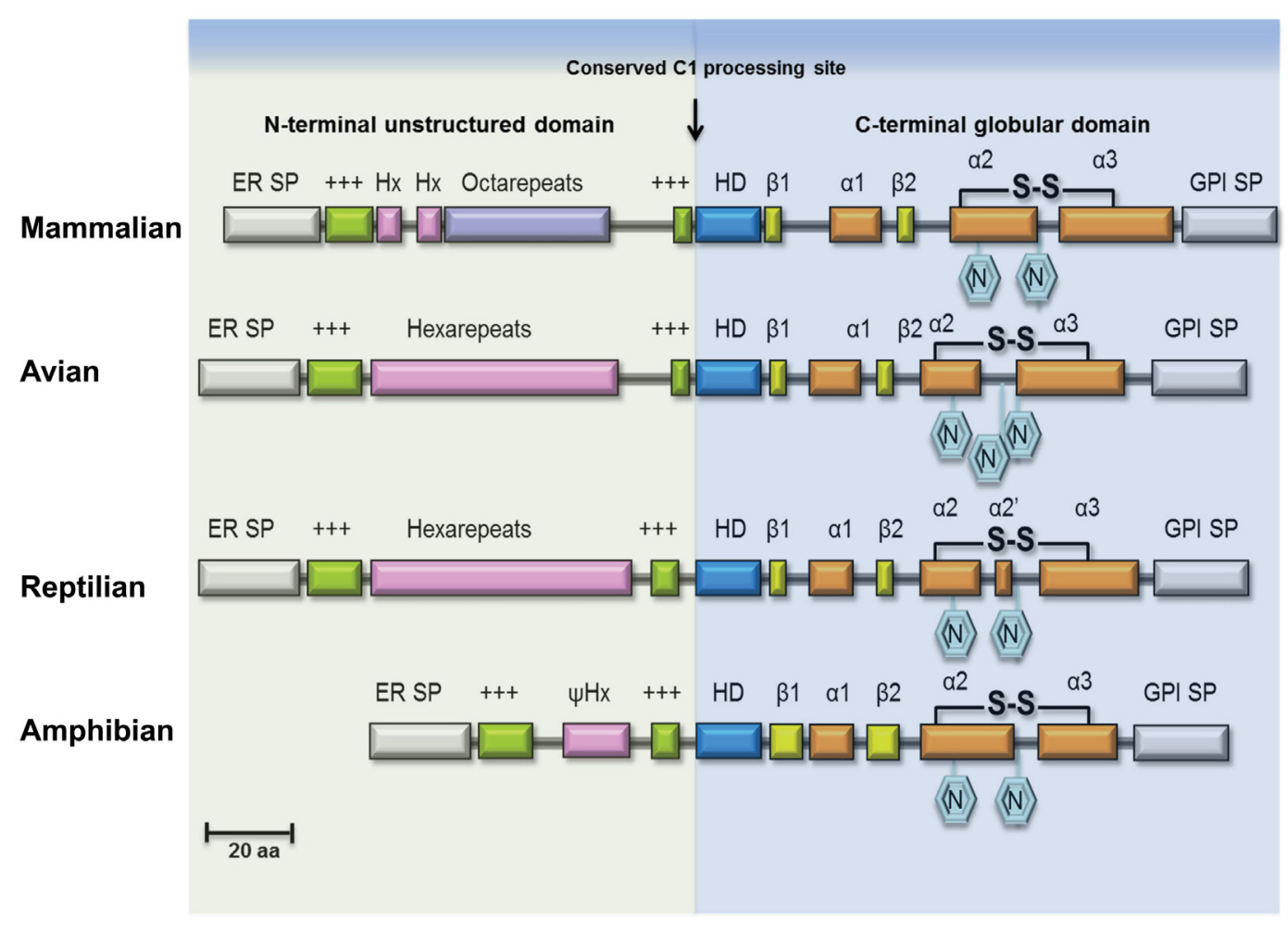

FIGURE 1 | Structural features of $\operatorname{PrP}^{\mathrm{C}}$ in vertebrate lineages. Schematic illustration of major structural features of $\mathrm{PrP}^{\mathrm{C}}$ in terrestrial vertebrates. The ER transfer signal peptide (ER SP) and the glycophosphatidylinositol-anchor attachment signal peptide (GPI SP) are removed during maturation of the primary translation product, followed by $\mathrm{N}$-glycosylation and cysteine bridge formation in the $\mathrm{C}$-terminus. The $\mathrm{N}$-terminal domain is an intrinsically disordered region (IDR) of variable length containing repeated sequence elements (pink/purple) flanked by two positively charged amino-acids motifs (green). In mammalian $\mathrm{PrP}^{\mathrm{c}}$, this region contains a number of glycine-rich octapeptides or nonapeptides, preceded by two hexapeptides, while in avian and reptilian $\mathrm{PrPc}^{\mathrm{C}}$ it is comprised entirely of hexapeptides, and in amphibian $\mathrm{PrP}^{\mathrm{C}}$ only a very short pseudo-hexapeptide $(\psi \mathrm{Hx})$ sequence is present. A highly conserved hydrophobic, alanine-rich motif (HD) at the center is characteristic for $\operatorname{PrP}^{\mathrm{C}}$. Proteolytic cleavage of $\mathrm{PrP}^{\mathrm{C}}$, known as $\alpha$-cleavage (arrow) occurs $\mathrm{N}$-terminal to the HD-motif at the boundary between the IDR domain and the globular C-terminal domain thus generating the fragments PrP-N1 and PrP-C1 of $\mathrm{PrP}^{\mathrm{C}}$ (not shown). The globular domain consists in most PrPs of three helices $(\alpha 1, \alpha 2, \alpha 3)$ and a $\beta$-sheet formed by two short $\beta$-strands $(\beta 1, \beta 2)$. was linked to the ability of the polypeptide chain to adopt a stable secondary/tertiary structure. This concept was extended when it became evident that intrinsically disordered region (IDRs) and proteins can participate in a broad range of defined physiological activities and play a major role in several protein classes, including transcription factors, scaffold proteins, and signaling molecules (34-36). This ability of IDRs to interact with many different substrates may explain the observation that $\mathrm{PrP}^{\mathrm{C}}$ can flexibly engage in a variety of supramolecular complexes (see below).

Considering the evolution of $\operatorname{PrP}^{\mathrm{C}}$, it is interesting to note that the three-dimensional structure of the globular C-terminal domain of human (121-230), chicken (121-225), turtle (121225), and xenopus (90-222) $\mathrm{PrP}^{\mathrm{C}}$ show extensive similarities, indicating a conserved activity (37). By contrast, the N-terminal IDR of $\operatorname{PrP}^{\mathrm{C}}$ shows high diversity between vertebrate classes. This is in line with the observation that IDRs often evolve more rapidly than well-structured protein domains (38). Many IDRs show sequence conservation, sometimes involving particular amino-acid residues, such as leucine (L), proline $(\mathrm{P})$, tyrosine (Y), and tryptophan (W) (39). The IDR of $\operatorname{PrP}^{\mathrm{C}}$ harbors many of these characteristics. Specifically, mammalian $\operatorname{PrP}^{\mathrm{C}_{S}}$ contain glycine-rich octarepeats with conserved W, $\mathrm{P}$, and histidine $(\mathrm{H})$ residues in this region $(18,40-46)$, while a hexarepeat region with conserved $\mathrm{P}, \mathrm{H}$, and $\mathrm{Y}$ is found in avian (47-49) and reptile $\operatorname{PrP}^{\mathrm{C}} \mathrm{S}$ (50). Strikingly, amphibian $\operatorname{PrP}^{\mathrm{C}}$ is devoid of any repeats and $H$ residues (51). Interestingly, IDRs are prevalent in virus proteins, allowing many interacting partners. Correspondingly, many proteins involved in innate immunity also carry IDRs, which may reflect the evolutionary "arms" race between invading pathogens and the host immune system. The evolutionary modifications that can be observed in the N-terminal IDR of $\mathrm{PrP}^{\mathrm{C}}$ among terrestrial vertebrates may indeed be a relic of these evolving immune functions. The most apparent evolutionary change that has occurred first in some reptilian species and then has become the norm in avian and mammalian $\operatorname{PrP}^{\mathrm{C}}$ are precisely spaced $\mathrm{H}$ residues which allow binding of divalent metal-ions, such as $\mathrm{Cu}^{2+}$ (52) and $\mathrm{Zn}^{2+}$ (53). $\mathrm{Cu}^{2+}$ binding will not only confer structural order to the $\mathrm{N}$-terminus (54) but also by operating as a sensitive regulator of the structural state of $\mathrm{PrP}^{\mathrm{C}}$ 's IDR it may govern protein interactions and proteolytic processing (PrP-N1/PrP-C1). 
Studies, comparing wild-type $\operatorname{PrP}^{\mathrm{C}}$ with mutated PrPs lacking the repeat region have shown that the octarepeat region is crucial for $\mathrm{PrP}^{\mathrm{C}}$ 's neuroprotective activity. For instance against Bax induced cell death (55) or toxicity caused by ectopic expression of the PrP-like protein Doppel (Dpl) $(56,57)$, excitotoxic stress and $\mathrm{PrP}^{\mathrm{Sc}}$ toxicity (58). Interestingly, Drisaldi and co-workers demonstrated that the neuroprotective function of the repeat region is dependent on four histidine residues (57). Furthermore, the repeat region is also necessary for the PrP-mediated neuroprotection observed in models of brain ischemia (59). Similarly, the ability of $\mathrm{PrP}^{\mathrm{C}}$ to transmit neurotoxic signaling of amyloid beta $(\mathrm{A} \beta)$ and other neurotoxic $\beta$-sheet-rich-conformers is greatly diminished in $\operatorname{PrP}^{\mathrm{C}}$ mutants devoid of this domain (60). Further studies of the mechanisms underlying the activities of the IDR of $\operatorname{PrP}^{\mathrm{C}}$ and its evolution, particularly in neuro-immune crosstalk appears to be an important area for future research.

Functionally, $\mathrm{PrP}^{\mathrm{C}}$ can by virtue of its GPI anchor move between membrane subdomains $(61,62)$, and interact with many partners at the cell surface. These partners may include other GPI-anchored molecules like the proteoglycan Glypican-1 (63), transmembrane proteins like the neural cell-adhesion molecule, NCAM (64), the low-density-related protein LRP1 (65), the amyloid precursor protein APP $(64,66)$, lipid raft constituents such as caveolin $(67)$, or src kinases $(68,69)$. The formation of these complexes may occur following the interaction of $\operatorname{PrP}^{\mathrm{C}}$ with extracellular matrix components, e.g., vitronectin (70) or laminin (71) or soluble ligands such as the extracellular chaperone stressinduced phosphoprotein 1 (STI1) (72). Moreover, in lymphoid cells $\mathrm{PrP}^{\mathrm{C}}$ has been shown to be recruited into microdomains of the membrane, the so-called immunological synapses harboring T-cell receptor components (73-76). As discussed above, many ligands appear to interact with the $\mathrm{N}$-terminal IDR of $\mathrm{PrP}^{\mathrm{C}}$ [reviewed in Ref. (77)].
Of major pathophysiological relevance is the ability of the $\mathrm{N}$-terminal PrP fragment (PrP-N1) to bind to and to mediate toxic effects of $\mathrm{A} \beta$ oligomers (78). $\mathrm{PrP}^{\mathrm{C}}$ may further engage into homophilic interactions or bind the two other members of the prion protein family Doppel and Shadoo $(58,68)$. It could be speculated that shed $\mathrm{PrP}^{\mathrm{C}}$ or $\mathrm{PrP}-\mathrm{N} 1$ can act at a distance via extracellular fluids. Indeed it has been demonstrated that soluble PrP-N1 fragments can prevent A $\beta$-induced toxicity and have a neuroprotective activity (79-84).

\section{PrP $^{\mathrm{C}}$ Pattern of Expression}

Although $\mathrm{PrP}^{\mathrm{C}}$ is ubiquitously expressed, its main expression overlaps strikingly with the distribution of immunologically quiescent sites (Figure 2). $\operatorname{PrP}^{\mathrm{C}}$ is abundantly present in the central and peripheral nervous system $(17,18,85)$, glial cells of the CNS $(86,87)$, and in the testes, eye, placenta, and uterus $(88,89) \cdot \operatorname{PrP}^{\mathrm{C}}$ is also present in the neurovascular unit, including endothelial cells $(90,91)$, it may thus be one of the protagonists modulating blood-brain barrier functions (92).

Cellular prion protein is also found in microglial cells (93). Whether its expression is associated with the inflammatory M1 producing TNF- $\alpha$, IL- $1 \beta$, and IL- 6 , or the immunosuppressive M2 (producing IL-10 and TGF- $\beta$ ) phenotype of microglia has not been clarified. Notwithstanding, the observation that Prnp knockout mice produce less of the anti-inflammatory cytokine IL-10 in response to LPS-induced chronic inflammation would suggest a positive role for $\mathrm{PrP}^{\mathrm{C}}$ in $\mathrm{M} 2$ microglia (94).

Cellular prion protein is abundantly expressed in neuronal and non-neuronal stem cells, including hematopoietic stem cells (HSCs) (95) and it contributes to stem-cell renewal, reviewed by Lopes and Santos (96) and Martin-Lannerée et al. (97). HSCs have been shown to co-localize with TREGs, suggesting that

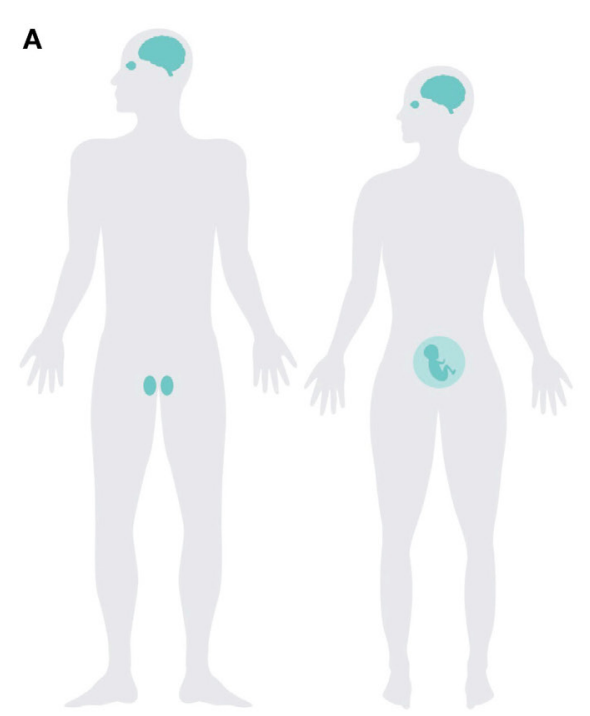

FIGURE 2 | The expression pattern of Prnp overlaps with immuneprivileged organs and extends into the lymphoreticular system. Schematic representation of (A) major immune-privileged organs; highlighting

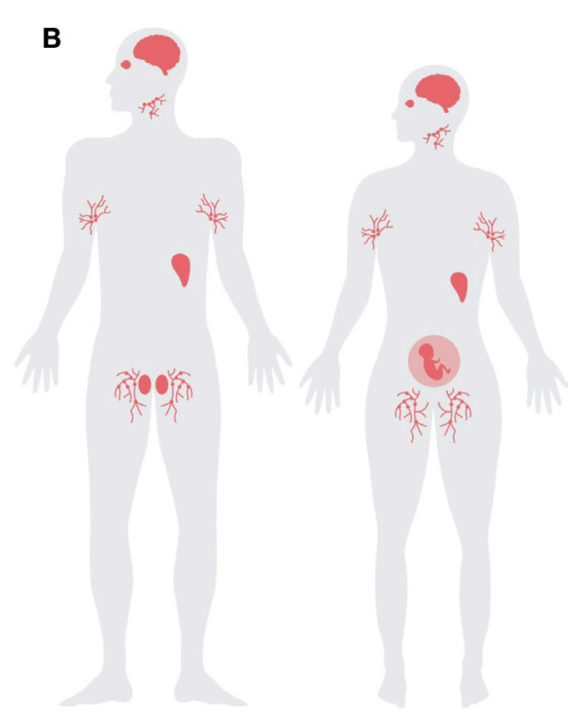

the brain, testes, pregnant uterus, and eye, and (B) the organs with highest levels of $\mathrm{PrP}^{\mathrm{C}}$ overlap with the immune-privileged organs with the addition of lymphoreticular tissues, illustrated with lymph nodes and the spleen. 
TREGs provide a "shield" conferring relative immune privilege to the HSCs (98). Interestingly, $\operatorname{PrP}^{\mathrm{C}}$ is found at high levels in both immature HSCs (95) and TREGs (99), and probably contributes to the interplay between HSCs and TREG cells in this niche.

Differentiation of HSCs along the lymphoid (100-102) or monocytic (103) lineages maintains the expression of surface $\operatorname{PrP}^{\mathrm{C}}$, while during the granulocyte maturation $\mathrm{PrP}^{\mathrm{C}}$ is downregulated (104). Within lymphoid cells, B cells express lower levels of $\mathrm{PrP}^{\mathrm{C}}$ compared to T cells and NK cells (105), which could be linked to the observation that $\mathrm{B}$ cells are not repressed in immuneprivileged sites. Regulatory $\mathrm{CD}^{+}{ }^{+} \mathrm{CD} 25^{+} \mathrm{T}$ cells expressed 4.5 fold higher levels of Prnp mRNA and showed a 10-fold higher intensity of surface $\mathrm{PrP}^{\mathrm{C}}$ than $\mathrm{CD} 4^{+} \mathrm{CD} 25^{-} \mathrm{T}$ cells (99). However, an attempt to identify the role of $\operatorname{PrP}^{\mathrm{C}}$ in TREGs using Prnp knockout mice was unsuccessful since no loss-of-function phenotypes could be recognized in Tregs without $\operatorname{PrP}^{\mathrm{C}}$ expression (99). In most immune cells, $\operatorname{PrP}^{\mathrm{C}}$ is dynamically expressed and generally naïve immune cells contain less $\operatorname{PrP}^{\mathrm{C}}$ than mature or stimulated immune cells, with a few exceptions $(105,106)$. Even neutrophils strongly upregulate $\operatorname{PrP}^{\mathrm{C}}$ levels after treatment with immunosuppressive TGF- $\beta$ or dexamethasone (107). On some immune cells, such as mast cells, Prnp is highly and constitutively expressed and $\mathrm{PrP}^{\mathrm{C}}$ is rapidly released from the cell surface when these cells are activated (108).

Following from the concept presented here, the principal role of $\mathrm{PrP}^{\mathrm{C}}$ in immune-privileged organs would be to protect against inflammatory damage. The dynamically regulated levels of $\mathrm{PrP}^{\mathrm{C}}$ observed in cells of the immune system, particularly the high expression in immunosuppressive TREGs, indicate that $\operatorname{PrP}^{\mathrm{C}}$ is important in immunological homeostasis.

\section{Inflammation Reveals Cytoprotective and Immunomodulatory Roles of PrPc}

Prnp knockout mice develop normally, with normal life expectancy $(109,110)$ and exhibit complete resistance toward prion infection. Despite a relative lack of robust and reproducible phenotypes under physiological conditions, a wide variety of roles for $\mathrm{PrP}^{\mathrm{C}}$ have been suggested, such as in maintenance of axonal myelin $(30,111)$, modulating circadian rhythms (112), and neuronal excitability (113). For a comprehensive review of suggested physiological roles of $\mathrm{PrP}^{\mathrm{C}}$, see Ref. (114). In addition to murine models, Prnp knockout cattle have been produced (115). After extensive analysis, under physiological conditions, only minor phenotypes were observed. Similar findings have been reported from a recently discovered line of Norwegian dairy goats, carrying a nonsense mutation that renders these animals devoid of $\operatorname{PrP}^{\mathrm{C}}(116,117)$.

Interestingly, experiments with Prnp knockout mice involving a diverse set of inflammatory processes (Table 1), such as experimental brain ischemia, brain trauma, experimental autoimmune encephalomyelitis (EAE), experimental colitis, and, intracerebral infection with encephalomyocarditis virus variant B (EMCV-B), have revealed that in the absence of $\operatorname{PrP}^{\mathrm{C}}$, inflammatory damage is greatly exacerbated; reviewed by Onodera et al. (118).

Experimental autoimmune encephalomyelitis in mice, a chronic demyelinating disease of the CNS and a model of multiple sclerosis
TABLE 1 | Loss of $\mathrm{PrP}^{\mathrm{C}}$ aggravates immunopathology in a variety of experimental settings.

\begin{tabular}{lccc}
\hline & \multicolumn{2}{c}{ Tissue damage } \\
\cline { 2 - 4 } Insult & Prnp wild type & $\begin{array}{c}\text { Prnp } \\
\text { knockout }\end{array}$ & Reference \\
\hline Brain ischemia & ++ & ++++ & $(59,119-122)$ \\
Brain trauma & ++ & ++++ & $(123,124)$ \\
Experimental autoimmune & ++ & ++++ & $(125,126)$ \\
encephalomyelitis (EAE) & & & \\
Experimental colitis & ++ & ++++ & $(127)$ \\
Encephalomyocarditis & ++ & ++++ & $(128)$ \\
Virus variant B & & &
\end{tabular}

aRefers to onset, duration, and severity of inflammation and magnitude of tissue damage.

in humans, is often induced by immunization with myelin oligodendrocyte glycoprotein (MOG). Autoantigen-specific T cells of both the Th1 and Th17 phenotypes cross the BBB and are the primary immune cells recruited to the CNS where they activate microglia and attract blood monocytes and other inflammatory cells (129). Induction of EAE by MOG injection in Prnp knockout mice resulted in earlier onset, prolonged and more severe neuroinflammation than in normal mice (125). The Prnp knockout mice had persisting T-cell and monocytic/microglial infiltrates in the CNS, accompanied by demyelination and axonal drop-out in spinal cord white matter. It was concluded that $\operatorname{PrP}^{\mathrm{C}}$ modulates T-cell-mediated neuroinflammation, with a suppressive effect on MOG-induced peripheral T-cell responses and the authors discussed whether the larger pathological lesions in mice lacking $\operatorname{PrP}^{\mathrm{C}}$ also could be caused by increased cellular susceptibility to oxidative stress.

Gourdain and colleagues (126) conducted experiments with reciprocal bone marrow chimeras with lack of $\operatorname{PrP}^{\mathrm{C}}$ expression in lymphoid cells or the CNS, but did not observe earlier disease onset nor increased leukocyte infiltration in the CNS in animals with Prnp knockout lymphocytes. However, they observed significantly higher pathology scores in mice lacking $\operatorname{PrP}^{\mathrm{C}}$ expression in the brain, and concluded that $\operatorname{PrP}^{\mathrm{C}}$ primarily confers neuroprotection against neuroinflammatory insult. In a different attempt to discriminate neuroprotection by $\operatorname{PrP}^{\mathrm{C}}$ from immunoregulatory roles, Hu and co-workers (130) used pharmacologically selective silencing of $\mathrm{PrP}^{\mathrm{C}}$ in lymphocytes in models of nervous system autoimmune disease. They were able to show that depletion of $\mathrm{PrP}^{\mathrm{C}}$ in lymphocytes directly affected T-cell activation, survival, and differentiation. In the absence of $\mathrm{PrP}^{\mathrm{C}}$ expression in lymphocytes, the severity of EAE was considerably increased. They concluded that lack of $\mathrm{PrP}^{\mathrm{C}}$ in lymphocytes resulted in pro-inflammatory activities and that autoimmune brain pathologies could develop despite protective $\mathrm{PrP}^{\mathrm{C}}$ expression in neuronal cells. Thus, under these experimental conditions, the role for $\mathrm{PrP}^{\mathrm{C}}$ as a regulator of immunological homeostasis apparently dominated the cytoprotective role of the protein in the CNS. In Gourdain et al. (126), the authors state that their data do not exclude an important role for $\mathrm{PrP}^{\mathrm{C}}$, particularly in early lymphoid responses. They further discuss several possible explanations for the conflicting results in their study and the study by $\mathrm{Hu}$ et al. (130). The models used are complicated and obviously differ in many aspects, such as mouse strain, encephalitogenic antigens, T-cell assay protocols 
and differences in methodology for gene silencing, all factors that may have contributed to the discrepancies.

In a different model with induction of focal brain ischemia, $\operatorname{Pr} n \mathrm{p}$ knockout mice experience more severe tissue damage after focal brain ischemia than wild-type mice $(59,119-121)$. Spudich and colleagues observed $200 \%$ larger infarct volume in Prnp knockout mice. In addition, an induction of ERK1/2, STAT1, JNK1/2, and Caspase- 3 activity in the Prnp knockouts suggests that these signaling molecules are involved in Prnp knockout-related neuronal cell death (120). Significantly increased infarction volumes were also observed in Prnp knockout mice, in studies of permanent and transient focal cerebral ischemia (121). Moreover, they observed reduced levels of phosphorylated Akt and enhanced neuronal caspase- 3 activation in Prnp knockout mice. In a rat stroke model, Shyu and colleagues revealed a time-dependent increase in $\mathrm{PrP}^{\mathrm{C}}$ levels in infarcted tissue to reach a peak 3 days post infarction and that overexpression of $\mathrm{PrP}^{\mathrm{C}}$ reduced ischemic injury (122). Mitsios and colleagues detected increased levels of $\operatorname{PrP}^{\mathrm{C}}$ in plasma from human stroke patients compared with healthy controls (131). Moreover, they found upregulation of $\operatorname{Pr}^{\mathrm{C}}$ in gray matter peri-infarcted tissue and in infarcted tissue, in 6 out of 10 patients. In a study of traumatic brain injury, Prnp knockout mice had a larger lesion volume and a breakdown of the blood-brain barrier 1 month after injury compared to wild-type mice (123). Interestingly, it has been observed that Prnp mRNA is one of two most upregulated mRNAs after induced traumatic brain injury in mice (124), supporting a protective role for $\operatorname{PrP}^{\mathrm{C}}$. From the studies on ischemic and traumatic brain injury, the role of inflammation in the development of lesions remains to be clarified, since no inflammation-specific parameters were measured, nor infiltration of cells along the borders of the necrotic tissue were observed. Cell death also activates inflammation and further studies should include the role of cytokines and immune cells, such as locally activated or blood-derived macrophages/microglia, when evaluating how $\operatorname{PrP}^{\mathrm{C}}$ influences damage control (94).

Intracranial infection with EMCV-B resulted in similar viral titers in wild-type and Prnp knockout mice, however, mice lacking $\operatorname{PrP}^{\mathrm{C}}$ showed higher numbers of apoptotic neurons, while wild-type mice had more activation of microglial cells as well as more severe infiltration of immune cells in the hippocampal area (128), suggesting that $\operatorname{PrP}^{\mathrm{C}}$ affected the inflammatory response, while also serving a protective, anti-apoptotic role during the infection.

In a mouse model of inflammatory bowel disease, mice lacking $\operatorname{Pr}^{\mathrm{C}}$ developed a more severe colitis with markedly elevated levels of pro-inflammatory cytokines and pro-apoptotic regulatory proteins (127). Moreover, it was shown that overexpression of $\mathrm{PrP}^{\mathrm{C}}$ protected against induction of colitis. Interestingly, lack of $\operatorname{PrP}^{\mathrm{C}}$ has been shown to skew T-cell development in favor of pro-inflammatory Th1 and Th17 phenotypes $(125,130)$.

Taken together, these observations made under different experimental modalities demonstrate that $\operatorname{Pr}^{\mathrm{C}}$ both mediates cytoprotective signaling under inflammatory stress and has the capacity to attenuate the inflammation itself.

In summary, $\mathrm{PrP}^{\mathrm{C}}$ is highly expressed in immune-privileged organs and it serves a protective role evident most clearly under inflammatory stress and/or tissue damage. Moreover, data show that $\operatorname{Pr}^{\mathrm{C}}$ is more than a passive protector, but also dampens the inflammation itself, by modulating the activity of immune cells in an anti-inflammatory direction. The latter role of $\mathrm{PrP}^{\mathrm{C}}$ fits well into the concept of immune privilege and immune modulation. The molecular details and signaling pathways by which $\operatorname{PrP}^{\mathrm{C}}$ modulates inflammation are not yet clarified and stand out as a challenging area of future research. Below, we highlight some of the current data on signaling mediated via or influenced by $\operatorname{PrP}^{\mathrm{C}}$ presence on the cell surface.

\section{$\mathrm{PrP}^{\mathrm{C}}$ in Cytoprotective and Immunoregulatory Signaling}

At a molecular level, the cytoprotective activity of $\operatorname{PrP}^{\mathrm{C}}$ may depend on its capacity to engage into multimolecular complexes at the cell surface and mobilize signal transduction cascades. For a review of these signaling events in neuronal cells, see Ref.(132). With respect to the concept presented here, the molecular cascades underlying the potential contribution of $\mathrm{PrP}^{\mathrm{C}}$ to immune quiescence remain to be dissected. However, many of these probably overlap with cytoprotective signaling, which is better characterized. We will therefore elaborate somewhat on $\operatorname{PrP}^{\mathrm{C}}$ partners and effectors potentially contributing to its cytoprotective activity (Figure 3). The extracellular co-chaperone STI1, identified as a $\mathrm{PrP}^{\mathrm{C}}$ partner in 1997 through a complementary hydropathy approach (133), is a well-established inducer of $\mathrm{PrP}^{\mathrm{C}}$-dependent signals. The STI1$\operatorname{PrP}^{\mathrm{C}}$ interaction has been shown to protect retinal $(72,134)$ and hippocampal neurons (135) against chemically induced apoptosis, in both cases via cAMP-dependent protein kinase A (PKA). The neuroprotective action of this partnership is also supported by the recruitment of mTOR (136) as well as the inactivation of the GSK3 $\beta$ kinase (69), whose overactivity is detrimental to neurons (137). Noteworthy, STI1 can be secreted from astrocytes (138), a cell type highly contributing to immune quiescence in the CNS (92). STI1 may act in a cell-autonomous manner to favor astrocytic differentiation upon binding to $\operatorname{Pr}^{\mathrm{C}}$ (139). Whether the STI1- $\operatorname{PrP}^{\mathrm{C}}$ interaction also instigates a dialog between astrocytes and neurons deserves to be considered. Interestingly, astrocytes release STI1 in response to oxygen-glucose deprivation (140), and thereby induce neuroprotective signals through $\operatorname{PrP}^{\mathrm{C}}$. In line with this, Lee and colleagues found that STI1 is induced in the ischemic brain and contributes to recovery via $\operatorname{PrP}^{\mathrm{C}}$ (141). The same study showed that the upregulation of STI1 promotes the recruitment of bone marrow-derived cells to the ischemic brain and thereby helps reducing brain injury. Although the full pathway of signaling events imparted by the STI1-PrPC duo in this context remains to be elucidated, a beneficial contribution of the downregulation of matrix-metallopeptidase 9 (MMP-9) transcripts and activity fostered by $\operatorname{PrP}^{\mathrm{C}}(142)$ should be proposed, since MMP-9 knockout mice are less vulnerable to ischemia than their wild-type counterparts (143), possibly because activation of MMPs during brain injury leads to increased permeability of the glia limitans (144), separating the perivascular space from the neural tissue proper and thereby opens for a higher flux of cells and solutes into the neuropil.

In addition to the mature brain, the cytoprotective action of the PrP ${ }^{\mathrm{C}}-\mathrm{STI1}$ interaction may operate during embryonic 


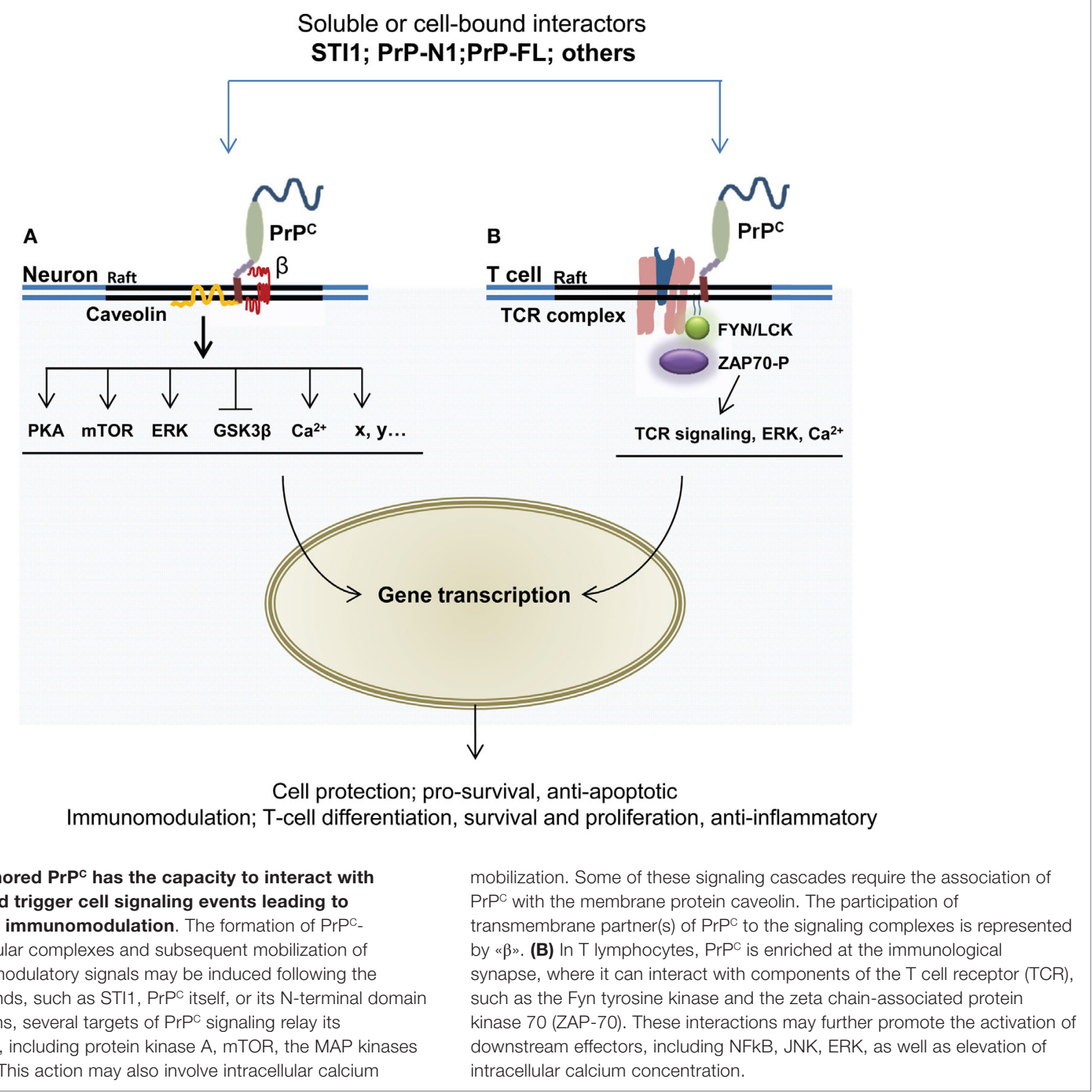

development since the two proteins are expressed from early stages $(140,145)$. Beraldo and colleagues reported that maternally derived STI1 can be found in blastocysts. Deletion of the STI1 gene in mice leads to embryonic lethality around E9-E10.5 due to placental disruption and lack of cellular viability (140). The molecular details causing embryonal lethality in the STI1 knockout mice have not been elucidated. This drastic phenotype implies that STI1 signaling in early embryos is relayed by several receptors beyond $\mathrm{PrP}^{\mathrm{C}}$. These include the activin receptor-like kinase-2 (ALK2) (146), whose deficiency leads to developmental arrest at the gastrulation stage (147). Another possibility to be considered is the binding of STI1 to the $\mathrm{PrP}^{\mathrm{C}}$ homolog Shadoo, which is abundantly expressed in extra-embryonic annexes, and which may have overlapping functions with $\mathrm{PrP}^{\mathrm{C}}$ during early development (148). Notwithstanding, because $\operatorname{PrP}^{\mathrm{C}}$ is abundant in extra-embryonic annexes (148), STI1- $\operatorname{PrP}^{\mathrm{C}}$ protective signaling is likely to also occur in placenta, another important site of immune privilege. With respect to embryonic development, it is worth noting that the binding of STI1 to $\operatorname{PrP}^{\mathrm{C}}$ enhances the self-renewal of neural progenitor cells (149). On the other side, however, STI1-PrP ${ }^{\mathrm{C}}$ signaling appears to contribute to tumor growth (150) (see below).

Regarding cells of the immunological lineage, it has long been known that $\mathrm{PrP}^{\mathrm{C}}$ is present on the surface of lymphocytes and that it is rapidly upregulated upon activation of these cells (100-102). Mattei and co-workers demonstrated that $\operatorname{PrP}^{\mathrm{C}}$ was part of a signaling complex involved in T-cell activation (73). Furthermore, through immunoprecipitation they observed an association between $\operatorname{PrP}^{\mathrm{C}}$ and the signaling tyrosine kinase Fyn, and, in activated $\mathrm{T}$ cells, $\operatorname{PrP}^{\mathrm{C}}$ was co-immunoprecipitated with zeta chain-associated protein kinase 70 (ZAP-70), a protein of central importance in T-cell receptor signaling. Upon silencing of $\mathrm{PrP}^{\mathrm{C}}$ in lymphocytes by Prnp siRNA, an increase in ZAP-70 activation was seen with a corresponding rise in $\mathrm{CD} 3 / \mathrm{CD} 28$ which 
was stimulated by transcription factor NFAT/AP-1, known for its function in T-cell signaling and differentiation (130). In Jurkat lymphocytes, a co-localization of $\mathrm{PrP}^{\mathrm{C}}$ and T-cell co-receptor CD3e and the lipid-raft ganglioside GM1 was observed $(74,76)$. Further compelling evidence of $\mathrm{PrP}^{\mathrm{C}}$ operating in immunological synapses, such as in antigen-driven interactions between $\mathrm{T}$ cells and DCs, have been reported (75). Interestingly, absence of $\mathrm{PrP}^{\mathrm{C}}$ in $\mathrm{T}$ cells and DCs had different consequences for T-cell proliferation; $\mathrm{T}$ cells devoid of $\mathrm{PrP}^{\mathrm{C}}$ exhibited a normal allogenic antigen response, while DCs without $\operatorname{PrP}^{\mathrm{C}}$ significantly reduced proliferation in interacting $\mathrm{T}$ cells, suggesting that $\operatorname{PrP}^{\mathrm{C}}$ might serve different signaling roles in the two cell types. From experiments using $\operatorname{PrP}^{\mathrm{C}}$ antibodies, the authors concluded that $\operatorname{PrP}^{\mathrm{C}}$ is a negative regulator of T-cell receptor signaling and that $\mathrm{PrP}^{\mathrm{C}}$ modulates neuroinflammation.

\section{$\mathrm{PrPC}^{\mathrm{C}}$ and Cancer}

While immune privilege represents a physiological safeguard mechanism, it is also known to be hijacked by cancer cells to evade antitumor immunity (151). Over a decade ago, $\operatorname{PrP}^{\mathrm{C}}$ was found to be overexpressed in a breast cancer cell line that was resistant to TNF $\alpha$-induced cell death (152). A correlation between $\mathrm{PrP}^{\mathrm{C}}$ expression and resistance to cytotoxic agents has now been described in various types of tumors, including breast cancer, gastric cancer, and glioblastoma [reviewed in Ref. (153)]. While the molecular mechanisms underlying the contribution of $\mathrm{PrP}^{\mathrm{C}}$ to tumor resistance are poorly understood, the disruption of the STI1 binding to $\mathrm{PrP}^{\mathrm{C}}$ was recently shown to impair glioblastoma growth (150), suggesting that cancer cells may usurp the cytoprotective activity of $\operatorname{PrP}^{\mathrm{C}}$. A question that deserves further investigation is whether the presence of $\operatorname{PrP}^{\mathrm{C}}$ at the surface of cancer cells endows them with properties that enable them to evade the immune response.

\section{Future Prospects}

Although the concept presented here allows many pieces of the $\mathrm{PrP}^{\mathrm{C}}$ puzzle to fall into place, by providing principal physiological roles of $\operatorname{PrP}^{\mathrm{C}}$ in all tissues, several important questions remain to

\section{References}

1. Prusiner SB. Prion diseases and central nervous system degeneration. Clin Res (1987) 35(3):177-91.

2. Aguzzi A, Calella AM. Prions: protein aggregation and infectious diseases. Physiol Rev (2009) 89(4):1105-52. doi:10.1152/physrev.00006.2009

3. Okin D, Medzhitov R. Evolution of inflammatory diseases. Curr Biol (2012) 22(17):R733-40. doi:10.1016/j.cub.2012.07.029

4. Niederkorn JY. See no evil, hear no evil, do no evil: the lessons of immune privilege. Nat Immunol (2006) 7(4):354-9. doi:10.1038/ni1328

5. Medawar PB. Immunity to homologous grafted skin. III. The fate of skin homographs transplanted to the brain, to subcutaneous tissue, and to the anterior chamber of the eye. Br J Exp Pathol (1948) 29(1):58-69.

6. Simpson E. A historical perspective on immunological privilege. Immunol $\operatorname{Rev}(2006)$ 213(1):12-22. doi:10.1111/j.1600-065X.2006.00434.x

7. Head JR, Neaves WB, Billingham RE. Immune privilege in the testis. I. Basic parameters of allograft survival. Transplantation (1983) 36(4):423-31. doi:10.1097/00007890-198310000-00014 be answered. For instance, does surface-bound $\mathrm{PrP}^{\mathrm{C}}$ on patrolling immune cells interact with $\mathrm{PrP}^{\mathrm{C}}$ or a $\mathrm{PrP}^{\mathrm{C}}$-controlled protein complex in tissues and cells, like in the blood-brain barrier tight junctions of the endothelial cells (90) and thereby sense the entrance into an immune-privileged, $\operatorname{PrP}^{\mathrm{C}}$-enriched zone; thus contributing to "do no harm" signaling? To what extent does $\mathrm{PrP}^{\mathrm{C}}$ play part in the maintenance of stem-cell niches, in the proliferation and differentiation of cell lineages derived from the bone marrow and in modulating the development of lymphoid organs? Furthermore, the concept presented here calls for careful scrutiny of the role of $\mathrm{PrP}^{\mathrm{C}}$ in chronic inflammatory conditions, such as inflammatory bowel disease and various pathologies eliciting inflammation in the brain or other immune-privileged organs.

Besides, in all these questions, we have to examine which of the many $\mathrm{PrP}^{\mathrm{C}}$ protein/peptide forms are the actual executors of these physiological roles. From the genomic perspective, it would be of great help to understand the gene control of Prnp and whether other immunomodulators, such as TRAIL, Fas/FasL, and IDO, are part of the same expression network controlled by similar transcription factors; and whether there is genetic variation resulting in altered immune-privilege. Our proposed link between $\operatorname{PrP}^{\mathrm{C}}$ and immunological quiescence opens an exciting new avenue for the study of this protein beyond the chronic diseases of the CNS into the domain of the immune system, the reproductive system, and in sensatory organs. It will encourage the study of $\mathrm{PrP}^{\mathrm{C}}$ in several inflammatory conditions and cancer.

\section{Funding}

$\mathrm{MB}, \mathrm{AE}$, and MT were supported by funds from the Research Council of Norway and the Norwegian University of Life Sciences. SM-R is supported by funds from INSERM. JT is supported by grants from the Deutsche Forschungsgemeinschaft and the Max Planck Society. WG is supported by a BBSRC UK Strategic Programme Grant to The Roslin Institute.

\section{Acknowledgments}

The authors acknowledge Professors Lucy Robertson and Trygve Holmøy for critically reading the manuscript.

8. Galea I, Bechmann I, Perry VH. What is immune privilege (not)? Trends Immunol (2007) 28(1):12-8. doi:10.1016/j.it.2006.11.004

9. Forrester JV, Xu H, Lambe T, Cornall R. Immune privilege or privileged immunity? Mucosal Immunol (2008) 1(5):372-81. doi:10.1038/ mi.2008.27

10. Dürr S, Kindler V. Implication of indolamine 2,3 dioxygenase in the tolerance toward fetuses, tumors, and allografts. J Leukoc Biol (2013) 93(5):681-7. doi:10.1189/jlb.0712347

11. Ferguson TA, Griffith TS. A vision of cell death: fas ligand and immune privilege 10 years later. Immunol Rev (2006) 213(1):228-38. doi:10.1111/j.1600-065X.2006.00430.x

12. Phillips TA, Ni J, Pan G, Ruben SM, Wei Y-F, Pace JL, et al. TRAIL (Apo-2L) and TRAIL receptors in human placentas: implications for immune privilege. J Immunol (1999) 162(10):6053-9.

13. WahlSM,WenJ,MoutsopoulosN.TGF- $\beta$ :amobilepurveyorofimmuneprivilege. Immunol Rev (2006) 213(1):213-27. doi:10.1111/j.1600-065X.2006.00437.x

14. Li MWM, Mruk DD, Lee WM, Cheng CY. Connexin 43 is critical to maintain the homeostasis of the blood-testis barrier via its effects on tight 
junction reassembly. Proc Natl Acad Sci U S A (2010) 107(42):17998-8003. doi:10.1073/pnas.1007047107

15. Boulay A-C, Mazeraud A, Cisternino S, Saubaméa B, Mailly P, Jourdren L, et al. Immune quiescence of the brain is set by astroglial connexin 43. $J$ Neurosci (2015) 35(10):4427-39. doi:10.1523/jneurosci.2575-14.2015

16. Shevach EM. Mechanisms of Foxp3+ T regulatory cell-mediated suppression. Immunity (2009) 30(5):636-45. doi:10.1016/j.immuni.2009.04.010

17. Chesebro B, Race R, Wehrly K, Nishio J, Bloom M, Lechner D, et al. Identification of scrapie prion protein-specific mRNA in scrapie-infected and uninfected brain. Nature (1985) 315(6017):331-3. doi:10.1038/315331a0

18. Oesch B, Westaway D, Wälchli M, McKinley MP, Kent SBH, Aebersold $\mathrm{R}$, et al. A cellular gene encodes scrapie PrP 27-30 protein. Cell (1985) 40:735-46. doi:10.1016/0092-8674(85)90333-2

19. Stahl N, Borchelt DR, Hsiao K, Prusiner SB. Scrapie prion protein contains a phosphatidylinositol glycolipid. Cell (1987) 51(2):229-40. doi:10.1016/0092-8674(87)90150-4

20. Haraguchi T, Fisher S, Olofsson S, Endo T, Groth D, Tarentino A, et al. Asparagine-linked glycosylation of the scrapie and cellular prion proteins. Arch Biochem Biophys (1989) 274(1):1-13. doi:10.1016/0003-9861(89)90409-8

21. Harris DA, Huber MT, van Dijken P, Shyng SL, Chait BT, Wang R. Processing of a cellular prion protein: identification of $\mathrm{N}$ - and C-terminal cleavage sites. Biochemistry (1993) 32(4):1009-16. doi:10.1021/bi00055a003

22. Chen SG, Teplow DB, Parchi P, Teller JK, Gambetti P, Autilio-Gambetti L. Truncated forms of the human prion protein in normal brain and in prion diseases. J Biol Chem (1995) 270(32):19173-80. doi:10.1074/ jbc.270.32.19173

23. McDonald AJ, Millhauser GL. PrP overdrive: does inhibition of alpha-cleavage contribute to $\operatorname{PrP}(\mathrm{C})$ toxicity and prion disease? Prion (2014) 8(2): 183-191. doi:10.4161/pri.28796

24. Walmsley AR, Watt NT, Taylor DR, Perera WS, Hooper NM. Alpha-cleavage of the prion protein occurs in a late compartment of the secretory pathway and is independent of lipid rafts. Mol Cell Neurosci (2009) 40(2):242-8. doi:10.1016/j.mcn.2008.10.012

25. Altmeppen HC, Prox J, Puig B, Kluth MA, Bernreuther C, Thurm D, et al. Lack of a-disintegrin-and-metalloproteinase ADAM10 leads to intracellular accumulation and loss of shedding of the cellular prion protein in vivo. Mol Neurodegener (2011) 6:36. doi:10.1186/1750-1326-6-36

26. Altmeppen HC, Prox J, Krasemann S, Puig B, Kruszewski K, Dohler F, et al. The sheddase ADAM10 is a potent modulator of prion disease. eLife (2015) 4:1-28. doi:10.7554/eLife.04260

27. Mays CE, Coomaraswamy J, Watts JC, Yang J, Ko KW, Strome B, et al. Endoproteolytic processing of the mammalian prion glycoprotein family. FEBS J (2014) 281(3):862-76. doi:10.1111/febs.12654

28. Ehsani S, Salehzadeh A, Huo H, Reginold W, Pocanschi CL, Ren H, et al. LIV-1 ZIP ectodomain shedding in prion-infected mice resembles cellular response to transition metal starvation. J Mol Biol (2012) 422(4):556-74. doi:10.1016/j.jmb.2012.06.003

29. Campbell L, Gill AC, McGovern G, Jalland CM, Hopkins J, Tranulis MA, et al. The $\operatorname{PrP}(\mathrm{C}) \mathrm{C} 1$ fragment derived from the ovine A136R154R171PRNP allele is highly abundant in sheep brain and inhibits fibrillisation of fulllength $\operatorname{PrP}(\mathrm{C})$ protein in vitro. Biochim Biophys Acta (2013) 1832(6):826-36. doi:10.1016/j.bbadis.2013.02.020

30. Bremer J, Baumann F, Tiberi C, Wessig C, Fischer H, Schwarz P, et al. Axonal prion protein is required for peripheral myelin maintenance. Nat Neurosci (2010) 13(3):310-8. doi:10.1038/nn.2483

31. Donne DG, Viles JH, Groth D, Mehlhorn I, James TL, Cohen FE, et al. Structure of the recombinant full-length hamster prion protein $\operatorname{PrP}(29-$ 231): the N terminus is highly flexible. Proc Natl Acad Sci U S A (1997) 94(25):13452-7. doi:10.1073/pnas.94.25.13452

32. Riek R, Hornemann S, Wider G, Billeter M, Glockshuber R, Wuthrich K. NMR structure of the mouse prion protein domain $\operatorname{PrP}(121-321)$. Nature (1996) 382(6587):180-2. doi:10.1038/382180a0

33. Riek R, Hornemann S, Wider G, Glockshuber R, Wuthrich K. NMR characterization of the full-length recombinant murine prion protein, $\operatorname{mPrP}(23-$ 231). FEBS Lett (1997) 413(2):282-8. doi:10.1016/S0014-5793(97)00920-4

34. Uversky VN, Dunker AK. Understanding protein non-folding. Biochim Biophys Acta (2010) 1804(6):1231-64. doi:10.1016/j.bbapap.2010.01.017

35. Fuxreiter M, Tompa P. Fuzzy complexes: a more stochastic view of protein function. Adv Exp Med Biol (2012) 725:1-14. doi:10.1007/978-1-4614-0659-4_1
36. Wright PE, Dyson HJ. Intrinsically disordered proteins in cellular signalling and regulation. Nat Rev Mol Cell Biol (2015) 16(1):18-29. doi:10.1038/ nrm3920

37. Calzolai L, Lysek DA, Perez DR, Guntert P, Wuthrich K. Prion protein NMR structures of chickens, turtles, and frogs. Proc Natl Acad Sci U S A (2005) 102(3):651-5. doi:10.1073/pnas.0408939102

38. Brown CJ, Takayama S, Campen AM, Vise P, Marshall TW, Oldfield CJ, et al. Evolutionary rate heterogeneity in proteins with long disordered regions. $J$ Mol Evol (2002) 55(1):104-10. doi:10.1007/s00239-001-2309-6

39. Brown CJ, Johnson AK, Daughdrill GW. Comparing models of evolution for ordered and disordered proteins. Mol Biol Evol (2010) 27(3):609-21. doi:10.1093/molbev/msp277

40. Basler K, Oesch B, Scott M, Westaway D, Walchli M, Groth DF, et al. Scrapie and cellular PrP isoforms are encoded by the same chromosomal gene. Cell (1986) 46(3):417-28. doi:10.1016/0092-8674(86)90662-8

41. Kretzschmar HA, Stowring LE, Westaway D, Stubblebine WH, Prusiner SB, Dearmond SJ. Molecular cloning of a human prion protein cDNA. DNA (1986) 5(4):315-24. doi:10.1089/dna.1986.5.315

42. Liao YC, Lebo RV, Clawson GA, Smuckler EA. Human prion protein cDNA: molecular cloning, chromosomal mapping, and biological implications. Science (1986) 233(4761):364-7. doi:10.1126/science.3014653

43. Liao YC, Tokes Z, Lim E, Lackey A, Woo CH, Button JD, et al. Cloning of rat "prion-related protein" cDNA. Lab Invest (1987) 57(4):370-4.

44. Westaway D, Goodman PA, Mirenda CA, McKinley MP, Carlson GA, Prusiner SB. Distinct prion proteins in short and long scrapie incubation period mice. Cell (1987) 51(4):651-62. doi:10.1016/0092-8674(87)90134-6

45. Goldmann W, Hunter N, Foster JD, Salbaum JM, Beyreuther K, Hope J. Two alleles of a neural protein gene linked to scrapie in sheep. Proc Natl Acad Sci U S A (1990) 87(7):2476-80. doi:10.1073/pnas.87.7.2476

46. Stewart P, Campbell L, Skogtvedt S, Griffin KA, Arnemo JM, Tryland M, et al. Genetic predictions of prion disease susceptibility in carnivore species based on variability of the prion gene coding region. PLoS One (2012) 7(12):e50623. doi:10.1371/journal.pone.0050623

47. Harris DA, Falls DL, Johnson FA, Fischbach GD. A prion-like protein from chicken brain copurifies with an acetylcholine receptor-inducing activity. Proc Natl Acad Sci U S A (1991) 88(17):7664-8. doi:10.1073/pnas.88.17.7664

48. Gabriel JM, Oesch B, Kretzschmar H, Scott M, Prusiner SB. Molecular cloning of a candidate chicken prion protein. Proc Natl Acad Sci U S A (1992) 89(19):9097-101. doi:10.1073/pnas.89.19.9097

49. Wopfner F, Weidenhöfer G, Schneider R, von Brunn A, Gilch S, Schwarz TF, et al. Analysis of 27 mammalian and 9 avian PrPs reveals high conservation of flexible regions of the prion protein. J Mol Biol (1999) 289(5):1163-78. doi:10.1006/jmbi.1999.2831

50. Simonic T, Duga S, Strumbo B, Asselta R, Ceciliani F, Ronchi S. cDNA cloning of turtle prion protein. FEBS Lett (2000) 469(1):33-8. doi:10.1016/ S0014-5793(00)01232-1

51. Strumbo B, Ronchi S, Bolis LC, Simonic T. Molecular cloning of the cDNA coding for Xenopus laevis prion protein. FEBS Lett (2001) 508(2):170-4. doi:10.1016/S0014-5793(01)03027-7

52. Haigh CL, Marom SY, Collins SJ. Copper, endoproteolytic processing of the prion protein and cell signalling. Front Biosci (2010) 15:1086-104. doi: $10.2741 / 3663$

53. Watt NT, Taylor DR, Kerrigan TL, Griffiths HH, Rushworth JV, Whitehouse IJ, et al. Prion protein facilitates uptake of zinc into neuronal cells. Nat Commun (2012) 3:1134. doi:10.1038/ncomms2135

54. Viles JH, Cohen FE, Prusiner SB, Goodin DB, Wright PE, Dyson HJ. Copper binding to the prion protein: structural implications of four identical cooperative binding sites. Proc Natl Acad Sci U S A (1999) 96(5):2042-7. doi:10.1073/pnas.96.5.2042

55. Bounhar Y, Zhang Y, Goodyer CG, LeBlanc A. Prion protein protects human neurons against Bax-mediated apoptosis. J Biol Chem (1997) 276:39145-9. doi:10.1074/jbc.C100443200

56. Atarashi R, Nishida N, Shigematsu K, Goto S, Kondo T, Sakaguchi S, et al. Deletion of $\mathrm{N}$-terminal residues 23-88 from prion protein (PrP) abrogates the potential to rescue PrP-deficient mice from PrP-like protein/doppel-induced neurodegeneration. J Biol Chem (2003) 278(31):28944-9. doi:10.1074/jbc. M303655200

57. Drisaldi B, Coomaraswamy J, Mastrangelo P, Strome B, Yang J, Watts JC, et al. Genetic mapping of activity determinants within cellular prion proteins: 
$\mathrm{N}$-terminal modules in PrPC offset pro-apoptotic activity of the doppel helix B/B' region. J Biol Chem (2004) 279(53):55443-54. doi:10.1074/jbc. M404794200

58. Rambold AS, Müller V, Ron U, Ben-Tal N, Winklhofer KF, Tatzelt J. Stressprotective activity of prion protein is corrupted by scrapie-prions. EMBO J (2008) 27:1974-84. doi:10.1038/emboj.2008.122

59. Mitteregger G, Vosko M, Krebs B, Xiang W, Kohlmannsperger V, Nolting S, et al. The role of the octarepeat region in neuroprotective function of the cellular prion protein. Brain Pathol (2007) 17(2):174-83. doi:10.1111/j.1750-3639.2007.00061.x

60. Resenberger UK, Harmeier A, Woerner AC, Goodman JL, Muller V, Krishnan R, et al. The cellular prion protein mediates neurotoxic signalling of beta-sheet-rich conformers independent of prion replication. EMBO J (2011) 30(10):2057-70. doi:10.1038/emboj.2011.86

61. Vey M, Pilkuhn S, Wille H, Nixon R, DeArmond SJ, Smart EJ, et al. Subcellular colocalization of the cellular and scrapie prion proteins in caveolae-like membranous domains. Proc Natl Acad Sci U S A (1996) 93(25):14945-9. doi:10.1073/pnas.93.25.14945

62. Hooper NM, Taylor DR, Watt NT. Mechanism of the metal-mediated endocytosis of the prion protein. Biochem Soc Trans (2008) 36(Pt 6):1272-6. doi:10.1042/BST0361272

63. Mani K, Cheng F, Havsmark B, Jonsson M, Belting M, Fransson LA. Prion, amyloid beta-derived $\mathrm{Cu}(\mathrm{II})$ ions, or free $\mathrm{Zn}(\mathrm{II})$ ions support S-nitrosodependent autocleavage of glypican-1 heparan sulfate. J Biol Chem (2003) 278(40):38956-65. doi:10.1074/jbc.M300394200

64. Schmitt-Ulms G, Hansen K, Liu J, Cowdrey C, Yang J, DeArmond SJ, et al. Time-controlled transcardiac perfusion cross-linking for the study of protein interactions in complex tissues. Nat Biotechnol (2004) 22(6):724-31. doi:10.1038/nbt969

65. Taylor DR, Hooper NM. Role of lipid rafts in the processing of the pathogenic prion and Alzheimer's amyloid-beta proteins. Semin Cell Dev Biol (2007) 18(5):638-48. doi:10.1016/j.semcdb.2007.07.008

66. Kaiser DM, Acharya M, Leighton PL, Wang H, Daude N, Wohlgemuth S, et al. Amyloid beta precursor protein and prion protein have a conserved interaction affecting cell adhesion and CNS development. PLoS One (2012) 7(12):e51305. doi:10.1371/journal.pone.0051305

67. Mouillet-Richard S, Ermonval M, Chebassier C, Laplanche JL, Lehmann S, Launay JM, et al. Signal transduction through prion protein. Science (2000) 289(5486):1925-8. doi:10.1126/science.289.5486.1925

68. Watts JC, Huo H, Bai Y, Ehsani S, Jeon AH, Shi T, et al. Interactome analyses identify ties of $\operatorname{PrP}$ and its mammalian paralogs to oligomannosidic $\mathrm{N}$-glycans and endoplasmic reticulum-derived chaperones. PLoS Pathog (2009) 5(10):e1000608. doi:10.1371/journal.ppat.1000608

69. Hernandez-Rapp J, Martin-Lanneree S, Hirsch TZ, Pradines E, AlleaumeButaux A, Schneider B, et al. A $\operatorname{PrP}(C)$-caveolin-Lyn complex negatively controls neuronal GSK3beta and serotonin 1B receptor. Sci Rep (2014) 4:4881. doi:10.1038/srep04881

70. Hajj GN, Lopes MH, Mercadante AF, Veiga SS, da Silveira RB, Santos TG, et al. Cellular prion protein interaction with vitronectin supports axonal growth and is compensated by integrins. J Cell Sci (2007) 120(Pt 11):1915-26. doi: $10.1242 /$ jcs. 03459

71. Graner E, Mercadante AF, Zanata SM, Forlenza OV, Cabral AL, Veiga SS, et al. Cellular prion protein binds laminin and mediates neuritogenesis. Brain Res Mol Brain Res (2000) 76(1):85-92. doi:10.1016/ S0169-328X(99)00334-4

72. Zanata SM, Lopes MH, Mercadante AF, Hajj GN, Chiarini LB, Nomizo R, et al. Stress-inducible protein 1 is a cell surface ligand for cellular prion that triggers neuroprotection. EMBO J (2002) 21(13):3307-16. doi:10.1093/ emboj/cdf325

73. Mattei V, Garofalo T, Misasi R, Circella A, Manganelli V, Lucania G, et al. Prion protein is a component of the multimolecular signaling complex involved in T cell activation. FEBS Lett (2004) 560(1-3):14-8. doi:10.1016/ S0014-5793(04)00029-8

74. Wurm S, Paar C, Sonnleitner A, Sonnleitner M, Hoglinger O, Romanin C, et al. Co-localization of CD3 and prion protein in Jurkat lymphocytes after hypothermal stimulation. FEBS Lett (2004) 566(1-3):121-5. doi:10.1016/j. febslet.2004.03.114

75. Ballerini C, Gourdain P, Bachy V, Blanchard N, Levavasseur E, Grégoire $\mathrm{S}$, et al. Functional implication of cellular prion protein in antigen-driven interactions between $\mathrm{T}$ cells and dendritic cells. JImmunol (2006) 176(12):7254-62. doi:10.4049/jimmunol.176.12.7254

76. Paar C, Wurm S, Pfarr W, Sonnleitner A, Wechselberger C. Prion protein resides in membrane microclusters of the immunological synapse during lymphocyte activation. Eur J Cell Biol (2007) 86(5):253-64. doi:10.1016/j. ejcb.2007.03.001

77. Beland $\mathrm{M}$, Roucou $\mathrm{X}$. The prion protein unstructured N-terminal region is a broad-spectrum molecular sensor with diverse and contrasting potential functions. J Neurochem (2012) 120(6):853-68. doi:10.1111/j.1471-4159.2011.07613.x

78. Lauren J, Gimbel DA, Nygaard HB, Gilbert JW, Strittmatter SM. Cellular prion protein mediates impairment of synaptic plasticity by amyloid-beta oligomers. Nature (2009) 457(7233):1128-32. doi:10.1038/nature07761

79. Guillot-Sestier MV, Sunyach C, Druon C, Scarzello S, Checler F. The alpha-secretase-derived N-terminal product of cellular prion, N1, displays neuroprotective function in vitro and in vivo. J Biol Chem (2009) 284(51):35973-86. doi:10.1074/jbc.M109.051086

80. Resenberger UK, Winklhofer KF, Tatzelt J. Neuroprotective and neurotoxic signaling by the prion protein. Top Curr Chem (2011) 305:101-19. doi:10.1007/128_2011_160

81. Beland M, Motard J, Barbarin A, Roucou X. PrPC homodimerization stimulates the production of PrPC cleaved fragments PrPN1 and PrPC1. J Neurosci (2012) 32(38):13255-63. doi:10.1523/JNEUROSCI.2236-12.2012

82. Nieznanski K, Choi JK, Chen S, Surewicz K, Surewicz WK. Soluble prion protein inhibits amyloid-beta (Abeta) fibrillization and toxicity. J Biol Chem (2012) 287(40):33104-8. doi:10.1074/jbc.C112.400614

83. Fluharty BR, Biasini E, Stravalaci M, Sclip A, Diomede L, Balducci C, et al. An $\mathrm{N}$-terminal fragment of the prion protein binds to amyloid-beta oligomers and inhibits their neurotoxicity in vivo. J Biol Chem (2013) 288(11):7857-66. doi:10.1074/jbc.M112.423954

84. Beland M, Bedard M, Tremblay G, Lavigne P, Roucou X. Abeta induces its own prion protein $\mathrm{N}$-terminal fragment (PrPN1)-mediated neutralization in amorphous aggregates. Neurobiol Aging (2014) 35(7):1537-48. doi:10.1016/j. neurobiolaging.2014.02.001

85. Taraboulos A, Jendroska K, Serban D, Yang SL, DeArmond SJ, Prusiner SB. Regional mapping of prion proteins in brain. Proc Natl Acad Sci U S A (1992) 89(16):7620-4. doi:10.1073/pnas.89.16.7620

86. Moser M, Colello RJ, Pott U, Oesch B. Developmental expression of the prion protein gene in glial cells. Neuron (1995) 14(3):509-17. doi:10.1016/0896-6273(95)90307-0

87. Bertuchi FR, Bourgeon DMG, Landemberger MC, Martins VR, Cerchiaro G. PrPC displays an essential protective role from oxidative stress in an astrocyte cell line derived from PrPC knockout mice. Biochem Biophys Res Commun (2012) 418(1):27-32. doi:10.1016/j.bbrc.2011.12.098

88. Tanji K, Saeki K, Matsumoto Y, Takeda M, Hirasawa K, Doi K, et al. Analysis of PrPc mRNA by in situ hybridization on brain, placenta, uterus and testis of rats. Intervirology (1995) 38:309-15.

89. Johnson ML, Grazul-Bilska AT, Reynolds LP, Redmer DA. Prion (PrPC) expression in ovine uteroplacental tissues increases after estrogen-treatment in ovariectomized (OVX) ewes and during early pregnancy. Reproduction (2014) 148(1):1-10. doi:10.1530/REP-13-0548

90. Viegas P, Chaverot N, Enslen H, Perrière N, Couraud P-O, Cazaubon S. Junctional expression of the prion protein PrPC by brain endothelial cells: a role in trans-endothelial migration of human monocytes. J Cell Sci (2006) 119(22):4634-43. doi:10.1242/jcs.03222

91. Pflanzner T, Petsch B, Andre-Dohmen B, Muller-Schiffmann A, Tschickardt $S$, Weggen $S$, et al. Cellular prion protein participates in amyloid-beta transcytosis across the blood-brain barrier. J Cereb Blood Flow Metab (2012) 32(4):628-32. doi:10.1038/jcbfm.2012.7

92. Abbott NJ, Ronnback L, Hansson E. Astrocyte-endothelial interactions at the blood-brain barrier. Nat Rev Neurosci (2006) 7(1):41-53. doi:10.1038/ nrn 1824

93. Brown DR, Besinger A, Herms JW, Kretzschmar HA. Microglial expression of the prion protein. Neuroreport (1998) 9(7):1425-9. doi:10.1097/00001756-199805110-00032

94. Liu J, Zhao D, Liu C, Ding T, Yang L, Yin X, et al. Prion protein participates in the protection of mice from lipopolysaccharide infection by regulating the inflammatory process. J Mol Neurosci (2015) 55(1):279-87. doi:10.1007/ s12031-014-0319-2 
95. Zhang CC, Steele AD, Lindquist S, Lodish HF. Prion protein is expressed on long-term repopulating hematopoietic stem cells and is important for their self-renewal. Proc Natl Acad Sci U S A (2006) 103(7):2184-9. doi:10.1073/ pnas. 0510577103

96. Lopes MH, Santos TG. Prion potency in stem cells biology. Prion (2012) 6(2):142-6. doi:10.4161/pri.19035

97. Martin-Lannerée S, Hirsch TZ, Hernandez-Rapp J, Halliez S, Vilotte J-L, Launay J-M, et al. $\operatorname{PrP}(\mathrm{C})$ from stem cells to cancer. Front Cell Dev Biol (2014) 2:55. doi:10.3389/fcell.2014.00055

98. Fujisaki J, Wu J, Carlson AL, Silberstein L, Putheti P, Larocca R, et al. In vivo imaging of Tregs providing immune privilege to the hematopoietic stem cell niche. Nature (2011) 474(7350):216-9. doi:10.1038/nature10160

99. Isaacs JD, Garden OA, Kaur G, Collinge J, Jackson GS, Altmann DM. The cellular prion protein is preferentially expressed by $\mathrm{CD} 4(+)$ CD25(+) Foxp3(+) regulatory T cells. Immunology (2008) 125(3):313-9. doi:10.1111/j.1365-2567.2008.02853.x

100. Cashman NR, Loertscher R, Nalbantoglu J, Shaw I, Kascsak RJ, Bolton DC, et al. Cellular isoform of the scrapie agent protein participates in lymphocyte activation. Cell (1990) 61(1):185-92. doi:10.1016/0092-8674(90)90225-4

101. Mabbott NA, Brown KL, Manson J, Bruce ME. T-lymphocyte activation and the cellular form of the prion protein. Immunology (1997) 92(2):161-5. doi:10.1046/j.1365-2567.1997.00331.x

102. Li R, Liu D, Zanusso G, Liu T, Fayen JD, Huang JH, et al. The expression and potential function of cellular prion protein in human lymphocytes. Cell Immunol (2001) 207(1):49-58. doi:10.1006/cimm.2000.1751

103. Burthem J, Urban B, Pain A, Roberts DJ. The normal cellular prion protein is strongly expressed by myeloid dendritic cells. Blood (2001) 98(13):3733-8. doi:10.1182/blood.V98.13.3733

104. Dodelet VC, Cashman NR. Prion protein expression in human leukocyte differentiation. Blood (1998) 91(5):1556-61.

105. Dürig J, Giese A, Schulz-Schaeffer W, Rosenthal C, Schmücker U, Bieschke $\mathrm{J}$, et al. Differential constitutive and activation-dependent expression of prion protein in human peripheral blood leucocytes. Br J Haematol (2000) 108(3):488-95. doi:10.1046/j.1365-2141.2000.01881.x

106. Isaacs JD, Jackson GS, Altmann DM. The role of the cellular prion protein in the immune system. Clin Exp Immunol (2006) 146(1):1-8. doi:10.1111/j.1365-2249.2006.03194.x

107. Mariante RM, Nóbrega A, Martins RAP, Areal RB, Bellio M, Linden R. Neuroimmunoendocrine regulation of the prion protein in neutrophils. $J$ Biol Chem (2012) 287(42):35506-15. doi:10.1074/jbc.M112.394924

108. Haddon DJ, Hughes MR, Antignano F, Westaway D, Cashman NR, McNagny KM. Prion protein expression and release by mast cells after activation. $J$ Infect Dis (2009) 200(5):827-31. doi:10.1086/605022

109. Bueler H, Fischer M, Lang Y, Bluethmann H, Lipp H-P, DeArmond SJ, et al. Normal development and behaviour of mice lacking the neuronal cell-surface PrP protein. Nature (1992) 356(6370):577-82. doi:10.1038/356577a0

110. Manson JC, Clarke AR, Hooper ML, Aitchison L, McConnell I, Hope J. 129/ Ola mice carrying a null mutation in $\mathrm{PrP}$ that abolishes mRNA production are developmentally normal. Mol Neurobiol (1994) 8(2-3):121-7. doi:10.1007/ BF02780662

111. Baumann F, Tolnay M, Brabeck C, Pahnke J, Kloz U, Niemann HH, et al. Lethal recessive myelin toxicity of prion protein lacking its central domain. EMBO J (2007) 26(2):538-47. doi:10.1038/sj.emboj.7601510

112. Tobler I, Gaus SE, Deboer T, Achermann P, Fischer M, Rulicke T, et al. Altered circadian activity rhythms and sleep in mice devoid of prion protein. Nature (1996) 380(6575):639-42. doi:10.1038/380639a0

113. Walz R, Amaral OB, Rockenbach IC, Roesler R, Izquierdo I, Cavalheiro EA, et al. Increased sensitivity to seizures in mice lacking cellular prion protein. Epilepsia (1999) 40(12):1679-82. doi:10.1111/j.1528-1157.1999. tb01583.x

114. Linden R, Martins VR, Prado MAM, Cammarota M, Izquierdo I, Brentani RR. Physiology of the prion protein. Physiol Rev (2008) 88(2):673-728. doi:10.1152/physrev.00007.2007

115. Richt JA, Kasinathan P, Hamir AN, Castilla J, Sathiyaseelan T, Vargas F, et al. Production of cattle lacking prion protein. Nat Biotechnol (2007) 25(1):132. doi:10.1038/nbt1271

116. Benestad S, Austbo L, Tranulis M, Espenes A, Olsaker I. Healthy goats naturally devoid of prion protein. Vet Res (2012) 43(1):87. doi:10.1186/1297-9716-43-87
117. Reiten MR, Bakkebo MK, Brun-Hansen H, Lewandowska-Sabat AM, Olsaker I, Tranulis MA, et al. Hematological shift in goat kids naturally devoid of prion protein. Front Cell Dev Biol (2015) 3:44. doi:10.3389/fcell.2015.00044

118. Onodera T, Sakudo A, Tsubone H, Itohara S. Review of studies that have used knockout mice to assess normal function of prion protein under immunological or pathophysiological stress. Microbiol Immunol (2014) 58(7):361-74. doi:10.1111/1348-0421.12162

119. McLennan NF, Brennan PM, McNeill A, Davies I, Fotheringham A, Rennison KA, et al. Prion protein accumulation and neuroprotection in hypoxic brain damage. Am J Pathol (2004) 165(1):227-35. doi:10.1016/ S0002-9440(10)63291-9

120. Spudich A, Frigg R, Kilic E, Kilic Ü, Oesch B, Raeber A, et al. Aggravation of ischemic brain injury by prion protein deficiency: role of ERK-1/-2 and STAT-1. Neurobiol Dis (2005) 20(2):442-9. doi:10.1016/j.nbd.2005.04.002

121. Weise J, Sandau R, Schwarting S, Crome O, Wrede A, Schulz-Schaeffer W, et al. Deletion of cellular prion protein results in reduced Akt activation, enhanced postischemic caspase- 3 activation, and exacerbation of ischemic brain injury. Stroke (2006) 37(5):1296-300. doi:10.1161/01.STR.0000217262.03192.d4

122. Shyu W-C, Lin S-Z, Chiang M-F, Ding D-C, Li K-W, Chen S-F, et al. Overexpression of PrPC by adenovirus-mediated gene targeting reduces ischemic injury in a stroke rat model. J Neurosci (2005) 25(39):8967-77. doi:10.1523/jneurosci.1115-05.2005

123. Hoshino S, Inoue K, Yokoyama T, Kobayashi S, Asakura T, Teramoto A, et al. Prions prevent brain damage after experimental brain injury: a preliminary report. Acta Neurochir Suppl (2003) 86:297-9.

124. Marciano PG, Brettschneider J, Manduchi E, Davis JE, Eastman S, Raghupathi $R$, et al. Neuron-specific mRNA complexity responses during hippocampal apoptosis after traumatic brain injury. J Neurosci (2004) 24(12):2866-76. doi:10.1523/JNEUROSCI.5051-03.2004

125. Tsutsui S, Hahn JN, Johnson TA, Ali Z, Jirik FR. Absence of the cellular prion protein exacerbates and prolongs neuroinflammation in experimental autoimmune encephalomyelitis. Am J Pathol (2008) 173(4):1029-41. doi:10.2353/ajpath.2008.071062

126. Gourdain P, Ballerini C, Nicot AB, Carnaud C. Exacerbation of experimental autoimmune encephalomyelitis in prion protein $(\mathrm{PrPc})$-null mice: evidence for a critical role of the central nervous system. J Neuroinflammation (2012) 9:25. doi:10.1186/1742-2094-9-25

127. Martin GR, Keenan CM, Sharkey KA, Jirik FR. Endogenous prion protein attenuates experimentally induced colitis. Am J Pathol (2011) 179(5):2290301. doi:10.1016/j.ajpath.2011.07.025

128. Nasu-Nishimura $Y$, Taniuchi $Y$, Nishimura T, Sakudo A, Nakajima K, Ano $Y$, et al. Cellular prion protein prevents brain damage after encephalomyocarditis virus infection in mice. Arch Virol (2008) 153(6):1007-12. doi:10.1007/ s00705-008-0086-x

129. Murphy AC, Lalor SJ, Lynch MA, Mills KH. Infiltration of Th1 and Th17 cells and activation of microglia in the CNS during the course of experimental autoimmune encephalomyelitis. Brain Behav Immun (2010) 24(4):641-51. doi:10.1016/j.bbi.2010.01.014

130. Hu W, Nessler S, Hemmer B, Eagar TN, Kane LP, Leliveld SR, et al. Pharmacological prion protein silencing accelerates central nervous system autoimmune disease via T cell receptor signalling. Brain (2010) $133(\mathrm{Pt}$ 2):375-88. doi:10.1093/brain/awp298

131. Mitsios N, Saka M, Krupinski J, Pennucci R, Sanfeliu C, Miguel Turu M, et al. Cellular prion protein is increased in the plasma and peri-infarcted brain tissue after acute stroke. J Neurosci Res (2007) 85(3):602-11. doi:10.1002/ jnr.21142

132. Hirsch TZ, Hernandez-Rapp J, Martin-Lanneree S, Launay JM, MouilletRichard S. $\operatorname{PrP}(\mathrm{C})$ signalling in neurons: from basics to clinical challenges. Biochimie (2014) 104:2-11. doi:10.1016/j.biochi.2014.06.009

133. Martins VR, Graner E, Garcia-Abreu J, de Souza SJ, Mercadante AF, Veiga SS, et al. Complementary hydropathy identifies a cellular prion protein receptor. Nat Med (1997) 3(12):1376-82. doi:10.1038/nm1297-1376

134. Chiarini LB, Freitas AR, Zanata SM, Brentani RR, Martins VR, Linden R. Cellular prion protein transduces neuroprotective signals. EMBO J (2002) 21(13):3317-26. doi:10.1093/emboj/cdf324

135. Lopes MH, Hajj GN, Muras AG, Mancini GL, Castro RM, Ribeiro KC, et al. Interaction of cellular prion and stress-inducible protein 1 promotes neuritogenesis and neuroprotection by distinct signaling pathways. J Neurosci (2005) 25(49):11330-9. doi:10.1523/JNEUROSCI.2313-05.2005 
136. Roffe M, Beraldo FH, Bester R, Nunziante M, Bach C, Mancini G, et al. Prion protein interaction with stress-inducible protein 1 enhances neuronal protein synthesis via mTOR. Proc Natl Acad Sci U S A (2010) 107(29):13147-52. doi: $10.1073 /$ pnas. 1000784107

137. Grimes CA, Jope RS. The multifaceted roles of glycogen synthase kinase 3 beta in cellular signaling. Prog Neurobiol (2001) 65(4):391-426. doi:10.1016/ S0301-0082(01)00011-9

138. Hajj GN, Arantes CP, Dias MV, Roffe M, Costa-Silva B, Lopes MH, et al. The unconventional secretion of stress-inducible protein 1 by a heterogeneous population of extracellular vesicles. Cell Mol Life Sci (2013) 70(17):3211-27. doi:10.1007/s00018-013-1328-y

139. Arantes C, Nomizo R, Lopes MH, Hajj GN, Lima FR, Martins VR. Prion protein and its ligand stress inducible protein 1 regulate astrocyte development. Glia (2009) 57(13):1439-49. doi:10.1002/glia.20861

140. Beraldo FH, Soares IN, Goncalves DF, Fan J, Thomas AA, Santos TG, et al. Stress-inducible phosphoprotein 1 has unique cochaperone activity during development and regulates cellular response to ischemia via the prion protein. FASEB J (2013) 27(9):3594-607. doi:10.1096/fj.13-232280

141. Lee SD, Lai TW, Lin SZ, Lin CH, Hsu YH, Li CY, et al. Role of stress-inducible protein-1 in recruitment of bone marrow derived cells into the ischemic brains. EMBO Mol Med (2013) 5(8):1227-46. doi:10.1002/ emmm.201202258

142. Pradines E, Loubet D, Schneider B, Launay JM, Kellermann O, MouilletRichard S. CREB-dependent gene regulation by prion protein: impact on MMP-9 and beta-dystroglycan. Cell Signal (2008) 20(11):2050-8. doi:10.1016/j.cellsig.2008.07.016

143. Svedin P, Hagberg H, Savman K, Zhu C, Mallard C. Matrix metalloproteinase- 9 gene knock-out protects the immature brain after cerebral hypoxia-ischemia. J Neurosci (2007) 27(7):1511-8. doi:10.1523/JNEUROSCI.4391-06.2007

144. Bechmann I, Galea I, Perry VH. What is the blood-brain barrier (not)? Trends Immunol (2007) 28(1):5-11. doi:10.1016/j.it.2006.11.007

145. Tremblay P, Bouzamondo-Bernstein E, Heinrich C, Prusiner SB, DeArmond SJ. Developmental expression of PrP in the post-implantation embryo. Brain Res (2007) 1139:60-7. doi:10.1016/j.brainres.2006.12.055

146. Tsai CL, Tsai CN, Lin CY, Chen HW, Lee YS, Chao A, et al. Secreted stress-induced phosphoprotein 1 activates the ALK2-SMAD signaling pathways and promotes cell proliferation of ovarian cancer cells. Cell Rep (2012) 2(2):283-93. doi:10.1016/j.celrep.2012.07.002

147. Gu Z, Reynolds EM, Song J, Lei H, Feijen A, Yu L, et al. The type I serine/ threonine kinase receptor ActRIA (ALK2) is required for gastrulation of the mouse embryo. Development (1999) 126(11):2551-61.

148. Makzhami S, Passet B, Halliez S, Castille J, Moazami-Goudarzi K, Duchesne A, et al. The prion protein family: a view from the placenta. Front Cell Dev Biol (2014) 2:35. doi:10.3389/fcell.2014.00035

149. Santos TG, Silva IR, Costa-Silva B, Lepique AP, Martins VR, Lopes MH. Enhanced neural progenitor/stem cells self-renewal via the interaction of stress-inducible protein 1 with the prion protein. Stem Cells (2011) 29(7):1126-36. doi:10.1002/stem.664

150. Lopes MH, Santos TG, Rodrigues BR, Queiroz-Hazarbassanov N, Cunha IW, Wasilewska-Sampaio AP, et al. Disruption of prion protein-HOP engagement impairs glioblastoma growth and cognitive decline and improves overall survival. Oncogene (2014) 34(25):3305-14. doi:10.1038/onc.2014.261

151. Schatton T, Frank MH. Antitumor immunity and cancer stem cells. Ann N Y Acad Sci (2009) 1176:154-69. doi:10.1111/j.1749-6632.2009.04568.x

152. Diarra-Mehrpour M, Arrabal S, Jalil A, Pinson X, Gaudin C, Pietu G, et al. Prion protein prevents human breast carcinoma cell line from tumor necrosis factor alpha-induced cell death. Cancer Res (2004) 64(2):719-27. doi:10.1158/0008-5472.CAN-03-1735

153. Mehrpour M, Codogno P. Prion protein: from physiology to cancer biology. Cancer Lett (2010) 290(1):1-23. doi:10.1016/j.canlet.2009.07.009

Conflict of Interest Statement: The authors declare that the research was conducted in the absence of any commercial or financial relationships that could be construed as a potential conflict of interest.

Copyright (c) 2015 Bakkebø, Mouillet-Richard, Espenes, Goldmann, Tatzelt and Tranulis. This is an open-access article distributed under the terms of the Creative Commons Attribution License (CC BY). The use, distribution or reproduction in other forums is permitted, provided the original author(s) or licensor are credited and that the original publication in this journal is cited, in accordance with accepted academic practice. No use, distribution or reproduction is permitted which does not comply with these terms. 